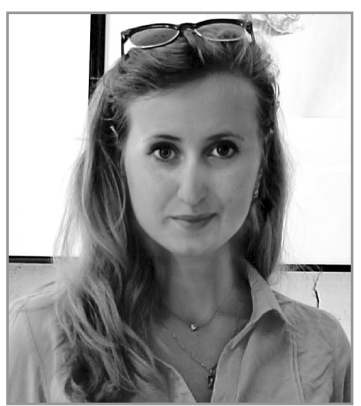

Yuliia Kolomiiets*

Magister of Law, Vilnius University

(Vilnius, Lithuania)

ORCID: https://orcid.org/0000-0003-2490-3565

*Yuliia Kolomiiets, Magister of Law, Vilnius University (3 Universiteto St., Vilnius, Lithuania).

UDC 347.799.6:330.34

DOI 10.26886/2524-101X.5.2019.2

\title{
SUSTAINABILITY CHALLENGES FOR THE MODERN SHIPPING: LEGAL ANALYSIS
}

\author{
ВИКЛИКИ СТАЛОГО РОЗВИТКУ \\ ДЛЯ СУЧАСНОГО СУДНОПЛАВСТВА: \\ ПРАВОВИЙ АНАЛІЗ
}

\begin{abstract}
It is well-known that $90 \%$ of international trade is carried by the sea, being the most important means of communication for economic and trade development. Because of nowadays technological development, shifting human needs and values, the shipping has been influenced by it also and shall reply on new challenges that appear behind. To maintain the balance between international trade and ecocaring, responding to modern issues, it is worth discovering shipping within the sustainability concept, which includes three pillars like environment, society, and economy and grounding on a legal basis. The roots of it refer to 1980s and United Nations, defining sustainable development as meeting the needs of the present without compromising the ability of future generations to meet their own needs. Then in 2016, it was embarked structured plan to change the world: Transforming our world: the 2030 Agenda for Sustainable Development. In my opinion, shipping must not be an exception also. Social pillar connected with human rights protection, involving different subjects as seafarers, as people in general effect by shipping activity. By the same token, there could be stressed out subject, which secures this
\end{abstract}


pillar like International organizations (as inter-governmental as non-governmental), states, ship-owners, etc. Third economic pillar concerns preventing to use financial tricks, getting around frauds like money laundering, Tax Evasion and Tax Avoidance for easy earning. One of the sources is in a free port zone. Besides, digitalization can help to improve maritime activity accounting sustainability. New cloud-based technologies such as big data platforms and digital twin technologies help to manage information, make decisions more quickly or reduce paper bureaucracy. Moreover, in 2019 United Nations Conference on Trade and Development proposed three stages for its accomplishment like optimization, extension, and transformation.

The key words: sustainable shipping, modern challenges, maritime law, digitalization, fiscal issues.

\section{Introduction}

The roots of application of the sustainable development concept to the international shipping can be traced to the IMO Convention, which "describes its fundamental purpose as the conservation and "sustainable" use of oceans and their resources" (Lee, Kwong, Ruan, 2019). Thus, the sustainability issues are considered to be naturally in focus of IMO and have influenced a number of international instruments that have been drafted within IMO frameworks. Furthermore, after the UN General Assembly endorsed the measures for sustainable development, agreed at the UN "Rio + 20 Summit on Sustainable Development" (Resolution on the future we want), IMO became "committed to producing sustainable development goals for the international shipping industry" (Sustainable Development).

Besides, remarkable efforts to pursue ideas of sustainable development into the shipping industry are made by private sector actors. Particularly, there is Sustainable Shipping Initiative, which reckons it through changing energy sources, using resources more efficiently and responsibly, and dramatically reducing greenhouse gas intensity; safe, healthy and secure work environments so that people want to work in shipping, where they can enjoy rewarding careers and achieve their full potential; the reputation of being a trusted and responsible partner in the communities where we live, work; financial solutions that reward sustainable performance and enable large-scale uptake of innovation, technology, design and operational efficiencies; transparency and accountability drive performance improvements and enable better, sustainable business decision-making; proactively contributing to the responsible governance of the oceans (Sustainable Shipping Initiative Vision 2040). 
But the realization of sustainable shipment ideas may also erect a series of challenges concerning conflicts between its particular objectives, results and interests. By the same token, thus law is empowered to follow and regulate modern tendency and output of sustainable development, that does not always manage.

\section{Increasing Environmental and Social Standards}

The IMO used to articulate that sustainable maritime transportation is a crosscutting issue, thus it is important enabler of Sustainable Development Goals (SDG) of the 2030 Agenda for Sustainable Development (Resolution on Transforming our world). For example, the continued efficient functioning of the maritime sector enables trade to flow freely and food and energy to be delivered cost-effectively throughout the globe (IMO and Sustainable Development). Thus, achieving the SDGs is apparently based upon the growing of the volumes of maritime transportation. On another hand, bigger production and trading around the world leads to breaching the balance in different fields like environment, human rights, shadow economy, that could be gathered in phenomena sustainability. The environment means the air, water, land in or on which people, animals and plans live. Therefore, under its components the impact can be observed.

The main sources of environmental pollution are marine engines and water used to wash cargo tanks, as well as ballast water. The engines of the ships emit the exhaust gases originally from the atmosphere, and from there toxic substances again fall into the waters of the hydrosphere. Fuel is also one of the source of pollution, particularly while ship crashes.

Moreover, during fast moments of the vessel, waves can cause the death of many aquatic organisms, including fish offspring. Like all modes of transport, water transport is a powerful concern for animals.

The intensification of shipping, in turn, means an increase in carbon dioxide $(\mathrm{CO} 2)$ emissions into the atmosphere, which leads to climate change. Understanding the problem International Maritime Organization ever in 1973 adopted the International Convention for the Prevention of Pollution from Ships (MARPOL), which has been amended by the Protocols of 1978 and 1997 and kept updated with relevant amendments. After there were adopted the line of conventions that regulate particular origin of pollution, for example The International Convention on Oil Pollution Preparedness, Response and Co-operation 1990. In fact, the Kyoto protocol does not cover neither sea nor air transport, although the agenda of the 15th and 16th 
conferences of the Parties to the UN Framework Convention on Climate Change (UNFCCC) included the inclusion of shipping requirements in the text of the new international agreement. But the point is efficiency of these regulations. We would like to highlight that environment impact will affect everyone as ship owner, as producer as the state and world in general starting from health effect of people towards natural disasters, involving various damages. So, in order to prevent it and maintain the situation on ecological care balance, all parties shall be interested and act to avoid more loses in future.

Regarding the second pillar of the sustainability like society, so during shipping it shall be accounted also. Mostly this area deals with consumer labor relations, that regulated corresponding legislation.

Given the increase in international travel and trade, as well as the emergence and re-entry the emergence of new international disease risks and health risk population, the Forty-eighth World Health Assembly in 1995 called for a substantial revision of the International Health Regulations adopted in 1969 year. In resolution WHA48.7, the Health Assembly invited the Director-General take steps to prepare this review, calling for broad participation and cooperation in this process.

In 2005 World Health Organization (WHO) adopted International Health Regulation like third edition to previous with goal to "to prevent, protect against, control and provide a public health response to the international spread of disease in ways that are commensurate with and restricted to public health risks, and which avoid unnecessary interference with international traffic and trade." The Regulation contains a range of innovations, including: (a) a scope not limited to any specific disease or manner of transmission, but covering "illness or medical condition, irrespective of origin or source, that presents or could present significant harm to humans"; (b) State Party obligations to develop certain minimum core public health capacities; (c) obligations on States Parties to notify WHO of events that may constitute a public health emergency of international concern according to defined criteria; (d) provisions authorizing WHO to take into consideration unofficial reports of public health events and to obtain verification from States Parties concerning such events; (e) procedures for the determination by the Director-General of a "public health emergency of international concern" and issuance of corresponding temporary recommendations, after taking into account the views of an Emergency Committee; (f) protection of the human rights of 
persons and travelers; and (g) the establishment of National IHR Focal Points and WHO IHR Contact Points for urgent communications between States Parties and WHO (International health regulations, 2016).

So, this regulation spread as for workers as for consumers, using shipping vogue for example. The issue is ineffective implementation these rules, enforcement, and responsibility. It is fatefully to view a ship's medical facility even to provide an emergent aid. More than 100 disease outbreaks associated with ships have been identified in the past 30 years. This is probably an underestimate because many outbreaks are not reported, and some may go undetected.

Another margin of the social pillar is the maintenance of human rights as the main value and fundamental rights during shipping, in particular seafarers' protection. International Labor Organization (ILO) has adopted over 70 instruments -41 Conventions and the related Recommendations for securing workers on the vessel (International Labour Standards on Seafarers).Among that instruments it should be allocated the major as the Maritime Labor Convention, 2006, ratified by 90 countries in 2019 and Revised Seafarers' Identity Documents Convention, 2003. Moreover 2011 UN Guiding Principles on Business and Human Rights in the maritime environment could be a useful tool also, although the UN Convention on the Law of the Sea (UNCLOS 1982), being which is the most comprehensive international convention, has no provisions for human rights. Vital role of human rights' protection at the sea is devoted to special Associations, NGOs, Unions, for instance Center for Seafarers' Rights (CSR), International Transport Workers' Federation (ITF Seafarers), Seafarers' Rights International (SRI).

In addition, nowadays challenges need complex regulation and involvement of many parties. To that end, we should mention the emerging concept of Human Rights at Sea, sponsored by the same-named charitable incorporated organization. The initial idea is based on the awareness that human rights for seafarers, fishermen, and others involved in working at sea need specific promotion. The present system of human rights protection based on states' jurisdiction where the state is responsible for enforcing respective international treaties on its territory. However, this approach at sea is not often effective enough.

Recognizing these problems, there were recently adopted Geneva Declaration on Human Rights at Sea of 5 April 2019 (Geneva Declaration on Human Rights at Sea, 2019) as a pattern for respective soft law. It is 
based on four fundamental principles like 1) human rights apply at sea to exactly the same degree and extent that they do on land; 2) all persons at sea, without any distinction, enjoy human rights at sea; 3 ) there are no maritime specific rules allowing derogation from human rights standards; 4) all human rights established under treaty and customary international law must be respected at sea.

\section{Facilitating Economic Development vs. Fiscal Concerns}

Third pillar in the sustainable concept concerns economic influence, that is far relevant for shipping. According to UNCTAD Review of Maritime Transport 2019 total volumes are estimated to have reached 11 billion tons, an all-time high. UNCTAD is also projecting 2.6 per cent growth in 2019 and an annual average growth rate of 3.4 per cent for the period 2019-2024 (Review of Maritime Transport, 2019). However, the maritime transportation has not only positive economic effect, but it is also often associated with different types of tax optimization and tax evasion practices.

One of the most important problems in this respect are the "flags of convenience" (FOC), registration under which have much more broad sequences that merely avoidance strict technical regulations. For example, the in the comments of International Transport Workers Federation on Panama Papers revelations it was highlighted that "Registering a ship under a FOC, where a vessel is owned in one country and flagged in another, is also a system of tax avoidance. As an FOC flag - the largest in the world - Panama is essentially a tax haven like many of the UK territories that have been mentioned in these papers" (ITF comment on Panama Papers revelations, 2016). Furthermore, I can be said that there are specific "tax heaven's" specialization on shipping industry. For example, one of the most important tax havens in this area is the Marshall Islands, which specializes in flags of convenience (Van Fossen, 2012).

The other source of tax evasion are free port zones. Such zones are physically inside a country but legally outside it for customs purposes. As well as zero tariffs, free ports pile on other goodies such as low taxes and loose regulation. Free ports are similar to free zones, or 'enterprise zones', which are designated areas subject to a broad array of special regulatory requirements, tax breaks and government support. The difference is that a free port is designed to specifically encourage businesses that import, process and then re-export goods, rather than more general business support or regeneration objectives. 
Basically, free ports have two main factors that make them attractive for shipping business:

- the customs extraterritoriality, which is the core characteristics of free ports and one that is present in every free port;

- the adaptation of free ports to wider ranges of services in order to cope with evolutions of supply chains, due to which logistics functions of free ports have become more complex and complete to cope with global supply chains and incorporate free ports in the international trade system (Lavissiere, Rodrigue, 2017, p. 8-9).

However, another side of free ports' attractiveness feature is increasing risks for financial crimes and smuggling. For example, such ill effects of free port legal regime can be summarized in three basic points, that are subject of criticism of certain EU institutions:

1) High security and discretion, that allow transactions to be made without attracting the attention of regulators or direct tax authorities. This include very liberal procedures of declaring the customs value;

2) The goods in free ports are technically 'in transit' thus, goods can enter a free port, stay there indefinitely and trade an unlimited number of times without ever having been taxed.

3) Goods entering free ports are not subject to customs duties and other taxes, thus no withholding tax is collected on capital gains, though sellers may need to report to the tax authority in the country where they are tax resident (Korver, 2018).

Considering, that only in European and Mediterranean areas are located more than 60 gateway and hub free ports (Lavissiere, Rodrigue, 2017 , p. 6) the risks of tax evasion can be very sensible for a number of states. The complexity of possible legal responses to the issue is determined by the specific of legal regime of free ports. The main instrument, which sets up such regime, is the Union Customs Code (UCC). This act views free ports merely as a customs procedure (Title VII, Chapter 3, Section 3), thus customs authorities supervising said ports are not entitled to enforce any actions that goes beyond providing compliance with customs procedures. However, EU Directive 2015/849 on money laundering Article 2(3) j) explicitly refers to persons 'storing, trading or acting as intermediaries in the trade of works of art when this is carried out by free ports. And under these conditions, the UCC cannot be said to function as a sufficient guarantee against money laundering or tax evasion (Korver, 2018). 


\section{Sustainable Shipping and Digitalization}

Practically, the technological development and digitalization can help to improve maritime activity accounting sustainability. Ships have become sophisticated sensor hubs and data generators, producing and transmitting information from anywhere, often in real time. At the same time, advances in satellite communications are improving connectivity, allowing for massive increases in the volumes of data transferred at ever-lower cost. These digital information flows are driving the automation of processes and functions, and they can have a positive impact on safety, commercial, and environmental performance. Combining data streams from multiple sources allows the maritime industry to make better-informed decisions more quickly, creating more efficient and responsive organizations. New cloud-based technologies such as big data platforms and digital twin technologies are starting to have a dramatic effect on how the industry manages information and how vessels and their components are designed, built, and tested. A typical example of digitalization is the concept of unmanned vessels, which requires much more than just converting paper chart into digital ones.

The UNCTD also discover the issue of digitalization as way for further evolution in maritime industry. In June 2019, it proposed three stages for it accomplishment like optimization, extension and transformation (Digitalization in Maritime Transport, 2019). For instance, portcall optimizing vessel speeds and routes, can reduce carbon-dioxide emissions and waiting times in ports. Concerning extension, UNCTD means movement beyond efficiency to produce opportunities for new services and businesses. As a result of optimization and technology driven efficiencies, supply chains become more effective, and transportation costs drop. Consequently, it could lead economic growth. Moreover, Digitalization will transform not only the port and shipping business, but it will likely change the global geography of trade, as comparative advantages of nations will shift (Digitalization in Maritime Transport, 2019). Also competitiveness drives states to improve their standards, in order to stay on the market and earn more. Therefore, companies, will develop, they will make favorable impact on other involved parties and trading process. From UNCTAD report it is clear recommended technological and industrial capacities, human resource and cooperation for successful implementation the policy towards shipping elaboration. So, this policy deals with global standards, the promotion of technological 
innovation, while avoiding monopolistic outcomes, and the need to ensure that digitalization works towards the achievement of the Sustainable Development Goals.

\section{Conclusions}

Sustainable shipping means realization international trade within three pillars caring about the environment, society and economy. As it was noticed every fields provide legislative coverage, but the point is in its harmonization, without gaps and collisions and then following by subjects in the maritime industry. By the same token, another issue lays down in enforcement as mostly international tools are not binding with recommendatory character, refereeing to Soft Law. In my opinion, it would be worth creating a consolidated legal document for maintaining sustainable shipping that would overspread three pillars. But in order to achieve that balance it needs also organizational measures from the authority side or other subjects and technical tools in a particular field. Regarding governance International Maritime Organization has already strengthened links with national and international governments (EU, African Union, etc.), giving teeth to enforce standards and regulations. Besides, the implementation of a sustainable concept in the shipping industry will positively reflect as on the efficiency of the international trade process as on seafarers' welfare and the environment in general.

\section{REFERENCES}

Digitalization in Maritime Transport: Ensuring Opportunities for Development. UNCTAD Policy Brief, June 2019, 75. Retrieved from: https:/unctad.org/en/PublicationsLibrary/ presspb2019d4_en.pdf (2019, October, 10).

Directive 2015/849 on the prevention of the use of the financial system for the purposes of money laundering or terrorist financing, amending Regulation (EU) No 648/2012 of the European Parliament and of the Council, and repealing Directive 2005/60/EC of the European Parliament and of the Council and Commission Directive 2006/70/EC, 2015 (European Parliament, Council). OJ, L 141 5.6.2015, 73.

Geneva Declaration on Human Rights at Sea, 2019. Human Rights at Sea. Retrieved from: https://www.humanrightsatsea.org/wp-content/uploads/2019/04/HRAS_GENEVA_ DECLARATION_ON_HUMAN_RIGHTS_AT_SEA_5_April_2019_Version_1_ LOCKED.pdf (2019, October, 5).

$I M O$ and Sustainable Development (International Maritime Organization). Official website of IMO. Retrieved from: http://www.imo.org/en/MediaCentre/HotTopics/Documents/ IMO\%20SDG\%20Brochure.pdf (2019, October, 15). 
International health regulations 2005 -- 3 rd. ed. (2016) World Health Organization. Geneva. WHO Press.

International Labour Standards on Seafarers (International Labour Organisation). Official web-site of ILO. Retrieved from: https://www.ilo.org/global/standards/subjects-coveredby-international-labour-standards/seafarers/lang--en/index.htm (2019, October, 9).

ITF comment on Panama Papers revelations, 2016. Retrieved from: https:// www.itfglobal.org/pt/node/1249 (2019, October, 10).

Korver, R. (2018). Money laundering and tax evasion risks in free ports. EPRS. Brussels. DOI: $10.2861 / 092981$

Lavissiere, A., Rodrigue. J.-P. (2017). Free ports: towards a network of trade gateways. Journal of Shipping and Trade, 2:7. DOI: 10.1186/s41072-017-0026-6.

Lee, P., Kwong, O., Ruan. X. (2019). Sustainability Challenges in Maritime Transport and Logistics Industry and Its Way Ahead. Sustainability, 11, 1331. DOI: http://dx.doi.org/10.3390/su11051331

Regulation 952/2013 laying down the Union Customs Code (European Parliament, Council). OJ, L 269 10.10.2013, 1.

Resolution on The future we want, 2012 (General Assembly of United Nations). Official web-site of the UN. Retrieved from: https://undocs.org/A/RES/66/288 (2019, October, 10).

Resolution on Transforming our world: the 2030 Agenda for Sustainable Development, 2015 (General Assembly of United Nations). Official web-site of the UN. Retrieved from: https://undocs.org/A/RES/70/1 (2019, October, 10).

Review of Maritime Transport, 2019 (UNCTAD). (2019) Retrieved from: https://unctad.org/en/PublicationsLibrary/rmt2019_en.pdf (2019, October, 10).

Sustainable Development. IMO World Maritime Day 2013. International Chamber of Shipping. Retrieved from: https://www.ics-shipping.org/docs/default-source/resources/policy-tools/sustainable-development-imo-world-maritime-day-2013.pdf (2019, October, 10).

Sustainable Shipping Initiative Vision 2040. Retrieved from: https://www.ssi2040.org/ wp-content/uploads/2017/01/SSI_Vision_doc_web.pdf (2019, October, 9).

Van Fossen, A. (2012). Tax Havens and Sovereignty in the Pacific Islands. St. Lucia. University of Queensland Press.

\section{АНОТАЦІЯ}

Коломієць Ю. Виклики сталого розвитку для сучасного судноплавства: правовий аналіз. - Стаття.

Загальновідомо, що 90\% міжнародної торгівлі здійснюється морем, яке $\epsilon$ найважливішим засобом комунікації для розвитку економіки та торгівлі. Через сучасний технологічний розвиток, зміщення потреб і цінностей людини, судноплавство також зазнало значних впливів і намагається відповідати на нові виклики. 3 метою підтримання рівноваги між міжнародною торгівлею та еко- 
логічним захистом, відповідаючи на сучасні проблеми, необхідно розкрити напрями реформування судноплавства у рамках концепції сталого розвитку. Ця концепція поєднує такі три стовпи, що мають правову основу: навколишнє середовище, суспільство та економіка. Коріння такого реформування йде у 1980-і роки та роботу Організації Об'єднаних Націй, яка визначає сталий розвиток як задоволення потреб сьогодення без шкоди для можливостей майбутніх поколінь задовольняти власні потреби. У 2016 році було розроблено структурований план зміни світу “Трансформація нашого світу: порядок денний до 2030 року для сталого розвитку”. На думку автора, судноплавство не повинно бути винятком. Соціальний стовп пов'язаний із захистом прав людини, включаючи різних суб'єктів, зокрема мореплавців. Це обумовлюється впливом людини на морську діяльність. Тим самим можна окреслити суб'єктів, що забезпечують функціонування цього стовпа: міжнародні організації (як міжурядові, так і неурядові), держави, судновласники тощо. Третій, економічний, стовп стосується запобігання використанню фінансових хитрощів, подолання шахрайства і таких його різновидів як відмивання грошей та ухилення від сплати податків. Одне з його джерел перебуває у сфері функціонування вільних портів. Крім того, цифрові технології можуть допомогти покращити стабільність обліку морської діяльності. Нові хмарні технології, зокрема великі платформи даних та цифрові технології-побратими, допомагають керувати інформацією, швидше приймати рішення та зменшити паперову бюрократію. Крім того, у 2019 році Конференція ООН з питань торгівлі та розвитку запропонувала три етапи ії здійснення: оптимізація, розширення та трансформація.

Ключові слова: стійке судноплавство, сучасні виклики, морське право, цифрові технології, фіскальні питання.

\section{АННОТАЦИЯ}

Коломиец Ю. Вызовы устойчивого развития для современного судоходства: правовой анализ. - Статья.

Общеизвестно, что 90\% международной торговли осуществляется морем важнейшим средством коммуникации для развития экономики и торговли. Благодаря современному технологическому развитию, смещению потребностей и ценностей человека, судоходство также претерпело значительные воздействия и пытается отвечать на новые вызовы. С целью поддержания равновесия между международной торговлей и экологической защитой, отвечая на современные проблемы, необходимо раскрыть направления реформирования судоходства в рамках концепции устойчивого развития. Эта концепция объединяет три столпа, имеющие правовую основу: окружающая среда, общество и экономика. Корнями такое реформирование уходит в 1980-е годы и работу Организации Объединенных Наций, которая определяет устойчивое развитие как удовлетворение потребностей настоящего без ущерба для возможностей будущих поколений удовлетворять собственные потребности. В 2016 году был разработан структурированный план изменения мира “Трансформация нашего мира: повестка 
дня до 2030 года для устойчивого развития". По мнению автора, судоходство не должно быть исключением из этой деятельности. Социальный столп связан с защитой прав человека, включая различных субъектов, в частности, мореплавателей. Это объясняется влиянием человека на морскую деятельность. Тем самым можно определить субъектов, обеспечивающих функционирование этого столпа: международные организации (как межправительственные, так и неправительственные), государства, судовладельцы и тому подобное. Третий, экономический, столп касается предотвращения использования финансовых махинаций, преодоления мошенничества и таких его разновидностей как отмывание денег и уклонение от уплаты налогов. Один из его источников пребывает в сфере функционирования свободных портов. Кроме того, цифровые технологии могут помочь улучшить стабильность учета морской деятельности. Новые облачные технологии, в частности, большие платформы данных и цифровые технологиипобратимы, помогают управлять информацией, быстрее принимать решения и уменьшить бумажную бюрократию. Кроме того, в 2019 году Конференция ООН по торговле и развитию предложила три этапа ее осуществления: оптимизация, расширение и трансформация.

Ключевые слова: устойчивое судоходство, современные вызовы, морское право, цифровые технологии, фискальные вопросы. 